\title{
Degradation of tartrazine dye from aqueous solution by heterogeneous fenton-like reaction on $\mathrm{Fe}_{2} \mathrm{O}_{3} / \mathrm{SiO}_{2}$ composite
}

\author{
Vu Van Tu, Vu Anh Tuan* \\ School of Chemical Engineering, Hanoi University of Science and Technology
}

Received 22 November 2016; Accepted for publication 28 August 2017

\begin{abstract}
In this study, $\mathrm{Fe}_{2} \mathrm{O}_{3} / \mathrm{SiO}_{2}$ composite was prepared by incipient impregnation method for degradation of tartrazine dye from aqueous solution by heterogeneous Fenton-like process. As-synthesized sample was characterized using X-ray diffraction (XRD), scanning electron microscopy (SEM), transmission electron microscopy (TEM) and $\mathrm{N}_{2}$ adsorptiondesorption isotherm. The results indicated that iron impregnation $(7 \mathrm{wt} . \%)$ did not significantly change specific area but it leads to a clear change in the porous structure of silica. The effects of different reaction parameters such as initial solution $\mathrm{pH}$, initial $\mathrm{H}_{2} \mathrm{O}_{2}$ concentration, and additive on the degradation of tartrazine were investigated. The optimal reacting conditions were found to be initial solution $\mathrm{pH} 3.0$, the $\mathrm{H}_{2} \mathrm{O}_{2}$ concentration of $12 \mathrm{mM}$, at a temperature of $30{ }^{\circ} \mathrm{C}$ with a dosage of catalyst $50 \mathrm{mg}$ and an initial dye concentration $50 \mathrm{mg} / \mathrm{L}$. Under optimal condition, $98.5 \%$ degradation efficiency of tartrazine was obtained within 80 min of reaction. The as-synthesized $\mathrm{Fe}_{2} \mathrm{O}_{3} / \mathrm{SiO}_{2}$ composite exhibited much better catalytic ability than commercial $\mathrm{Fe}_{2} \mathrm{O}_{3}$, as-synthesized $\mathrm{Fe}_{2} \mathrm{O}_{3}$, physical mixture $\mathrm{Fe}_{2} \mathrm{O}_{3} / \mathrm{SiO}_{2}$ under the same experimental condition. In addition, the effects of $\mathrm{NaCl}$ and EDTA in the degradation of dye and reaction mechanism were investigated.
\end{abstract}

Keywords. Heterogeneous fenton, composite, $\mathrm{Fe}_{2} \mathrm{O}_{3} / \mathrm{SiO}_{2}$, tartrazine, degradation.

\section{INTRODUCTION}

The discharge of several hazardous dyes from many textiles industries in waste water is the main cause of serious environmental problems that concerned with human health and the aquatic medium due to the toxicity and the carcinogenic effect of these materials [1]. Therefore, the removal of dyes from wastewater is a challenge to the related industries because of their high solubility in water, complex structure, and synthetic origin. Recently, advanced oxidation processes (AOPs) are promising substitute technologies for efficient elimination of organic pollutants from wastewater with high chemical stability and low biodegradability [2].

AOPs are based on the generation of nonselective $\mathrm{OH}^{\bullet}$ radicals, which one of the most powerful oxidation species to degrade organic compounds into nontoxic products (ideally $\mathrm{CO}_{2}, \mathrm{H}_{2} \mathrm{O}$ ) [3]. Homogenceous photo-Fenton is a common AOP, in which soluble iron II is the catalyst but the difficulty of catalyst recovery is a process drawback and tight $\mathrm{pH}$ range in which the reaction proceeds [4]. To overcome the disadvantages of the homogeneous Fenton process, some attempts have been made to develop heterogeneous catalysts, prepared by loading iron (III) oxide onto a porous support such as zeolites, clays, silica, activated carbon.

Recently, Fe-containing silica mesoporous has attracted much attention because of their high surface area and uniform pore size distribution. The catalytic activity strongly depends on the iron precursor and its preparation method. In the most previous investigation, iron (III) oxide supported on silica could be obtained via impregnation and sol-gel co-condensation. In general, impregnation could achieve higher loading of $\mathrm{Fe}$ on mesoporous support. In addition, the catalysts prepared by impregnation exhibited high efficient of organic dyes treatment and the negligible iron leaching from the catalyst.

The colour additive tartrazine, whose IUPAC name is trisodium 1-(4-sulfonatophenyl)-4-(4sulfonatophenylazo)-5-pyrazolone-3-carboxylate; CI number 19140; molecular formula $\mathrm{C}_{16} \mathrm{H}_{9} \mathrm{~N}_{4} \mathrm{Na}_{3} \mathrm{O}_{9} \mathrm{~S}_{2}$, molecular weight $(534.4 \mathrm{~mol} / \mathrm{g})$ was selected as a model of azo dye because it widespread use in food products, drugs, cosmetics, pharmaceuticals and for dying some textile fiber. Also, it causes asthma, eczema, thyroid cancer, and some other behavioral problems [5].

The main objective of the present work is synthesis of $\mathrm{Fe}_{2} \mathrm{O}_{3} / \mathrm{SiO}_{2}$ composite via the simply incipient impregnation method. The catalytic ability 
of composite was evaluated by the degradation of tartrazine in the presence of $\mathrm{H}_{2} \mathrm{O}_{2}$. The effect of different reaction parameters such as initial solution $\mathrm{pH}$, initial $\mathrm{H}_{2} \mathrm{O}_{2}$ concentration and additive on the degradation of tartrazine were investigated to figure out the optimal reacting conditions. The catalytic ability of as-synthesized $\mathrm{Fe}_{2} \mathrm{O}_{3} / \mathrm{SiO}_{2}$ composite was compared to the commercial material $\left(\mathrm{Fe}_{2} \mathrm{O}_{3}\right.$ and $\mathrm{SiO}_{2}$ ), as-synthesized $\mathrm{Fe}_{2} \mathrm{O}_{3}$, and a physic mixture of as-synthesized $\mathrm{Fe}_{2} \mathrm{O}_{3}$ and $\mathrm{SiO}_{2}$. In addition, effects of $\mathrm{NaCl}$ and EDTA in the degradation of dye and reaction mechanism were studied.

\section{EXPERIMENTAL}

\subsection{Chemicals and regents}

Tartrazine was purchased from Sigma-Aldrich without any purification. $\mathrm{SiO}_{2}$ powder (GF254 for thin layer chromatography), $\mathrm{Fe}\left(\mathrm{NO}_{3}\right)_{3} .9 \mathrm{H}_{2} \mathrm{O}(99.5$ $\%), \mathrm{H}_{2} \mathrm{O}_{2}(30 \% \mathrm{w} / \mathrm{w}), \mathrm{NaCl}(99.7 \%)$, EDTA (99.5 $\%)$ were obtained from Merck. Distilled water was used throughout the experiments. The initial $\mathrm{pH}$ of the solution was adjusted to the desired value using dilute solutions of $\mathrm{H}_{2} \mathrm{SO}_{4}$ and $\mathrm{NaOH}$.

\subsection{Preparation of catalyst}

The $\mathrm{Fe}_{2} \mathrm{O}_{3} / \mathrm{SiO}_{2}$ composite was prepared by incipient impregnation method. The iron content in composite was about $7 \mathrm{wt} \%$ in theory. Typically, $1.44 \mathrm{~g}$ of silica powder immersed in $10 \mathrm{~mL}$ of $\mathrm{Fe}\left(\mathrm{NO}_{3}\right)_{3} 2.0 \mathrm{M}$ solution under vigorous stirring for $24 \mathrm{~h}$ at room temperature. After impregnation, the sample was dried at $80{ }^{\circ} \mathrm{C}$ for $24 \mathrm{~h}$ and then followed by calcination at $500{ }^{\circ} \mathrm{C}$ for $5 \mathrm{~h}$ in a muffle furnace. Then, it was cooled to room temperature and stored in a stoppered bottle (denote as as-synthesized $\mathrm{Fe}_{2} \mathrm{O}_{3} / \mathrm{SiO}_{2}$ ) for catalytic use.

Commercial $\mathrm{Fe}_{2} \mathrm{O}_{3}$, as-synthesized $\mathrm{Fe}_{2} \mathrm{O}_{3}$ prepared by vaporizing $\mathrm{Fe}\left(\mathrm{NO}_{3}\right)_{3}$ solution at $80{ }^{\circ} \mathrm{C}$ for $24 \mathrm{~h}$ and then calcined at $500{ }^{\circ} \mathrm{C}$ for $5 \mathrm{~h}$, and physical mixture $\mathrm{Fe}_{2} \mathrm{O}_{3} / \mathrm{SiO}_{2}$ prepared by mixed synthesized $\mathrm{Fe}_{2} \mathrm{O}_{3}$ with commercial $\mathrm{SiO}_{2}$ were compared with the as-synthesized $\mathrm{Fe}_{2} \mathrm{O}_{3} / \mathrm{SiO}_{2}$ composite for degradation of tartrazine from water solution.

\subsection{Characterization}

The crystalline phase of samples was investigated by X-ray powder diffraction. XRD patterns were obtained by using Bruker D8 Ax XRDdiffractometer (Germany) with $\mathrm{CuK} \alpha$ irradiation $(40 \mathrm{kV}, 40 \mathrm{~mA})$. The $2 \theta$ ranging from 10 to $70^{\circ}$ was selected to analyze the crystal structure.

The morphology and size of the samples were observed by transmission electron microscopy (TEM, JEM-2010) and field emission scanning electron microscopy (FE-SEM, JEOL-7600F). Energy Dispersive Spectrometry (EDS) was performed on JEOL-7600F to determine the chemical composition of the composite.

Textural properties were measured via $\mathrm{N}_{2}$ adsorption/desorption isotherm using a Quantachrome instrument (Autosorb iQ, version 3.0 analyzer). The specific surface area was calculated by using the Brunauer-Emmett-Teller (BET) method and the pore size distribution was obtained by using the Barrett-Joyner-Halenda (BJH) method.

\subsection{Catalytic activity study}

The experiment on the degradation of tartrazine was conducted in batch mode reactor. Typically, $50 \mathrm{mg}$ of catalyst and premeasured amounts of $\mathrm{H}_{2} \mathrm{O}_{2}$ solution were added to beaker $250 \mathrm{ml}$ containing $100 \mathrm{~mL}$ of $50 \mathrm{mg} / \mathrm{L}$ dye solution adjusted $\mathrm{pH}$ under magnetic stirring. At given time intervals, $2 \mathrm{~mL}$ of samples were withdrawn from the suspension and immediately filtered by using syringe filter (pore size $0.45 \mu \mathrm{m}$ ). The dye concentration of the filtrate was analyzed by a UV-Vis spectrophotometer (Agilent 8453) at the maximum absorbance wavelength $428 \mathrm{~nm}$. The degradation efficiency (\%) of tartrazine can be calculated by the following equation:

Degradation efficiency $(\%)=\frac{\mathrm{C}_{0-} \mathrm{C}_{\mathrm{t}}}{\mathrm{C}_{0}} \cdot 100 \%$

Where $\mathrm{C}_{0}(\mathrm{mg} / \mathrm{L})$ is the initial concentration of tartrazine and $\mathrm{C}_{\mathrm{t}}(\mathrm{mg} / \mathrm{L})$ is the concentration of tartrazine at reaction time, $\mathrm{t}(\mathrm{min})$.

\section{RESULTS AND DISCUSSION}

\subsection{Characterization of as-synthesized sample}

\subsubsection{SEM, TEM and EDS analysis}

Figure 1 reveals the FE-SEM, TEM and EDS spectrum of as-synthesized $\mathrm{Fe}_{2} \mathrm{O}_{3} / \mathrm{SiO}_{2}$ and commercial $\mathrm{SiO}_{2}$. The morphology of $\mathrm{Fe}_{2} \mathrm{O}_{3} / \mathrm{SiO}_{2}$ composite (Figure 1b) was different from commercial $\mathrm{SiO}_{2}$ (Figure 1a). However, both of samples showed the assembling morphology, the bulk shape was $10-20 \mathrm{~nm}$. The silica and iron could not be observed from SEM images however iron oxide nanoparticles of smaller size about $5 \mathrm{~nm}$ were well dispersed on silica particles, as seen in TEM image (figure 1 (c)). The $\mathrm{Fe}$ and $\mathrm{Si}$ contents were 
detected in EDS spectrum (figure 1d), $32.6 \mathrm{wt} \%$ and 7.7 wt.\%, respectively, this was close to the theory value of $\mathrm{Fe}$ ( $7 \mathrm{wt} . \%)$. These results showed that the $\mathrm{Fe}$ content could be transferred to iron (III) oxide and it was well dispersed on the $\mathrm{SiO}_{2}$ particles after incipient impregnation and calcination at $500{ }^{\circ} \mathrm{C}$ for $5 \mathrm{~h}$. The EDS spectra $\mathrm{Ca}$ and $\mathrm{S}$ could be attributed to the $\mathrm{CaSO}_{4}$ content in the commercial $\mathrm{SiO}_{2}$.

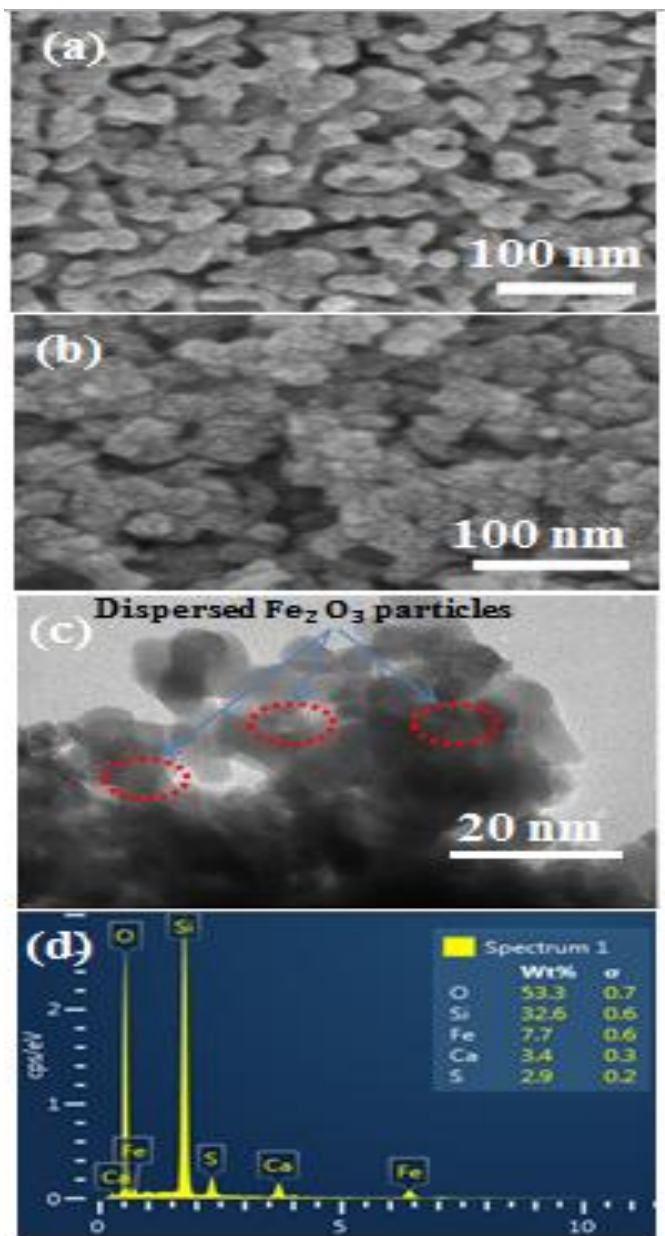

Figure 1: $\mathrm{SEM}$ images of $\mathrm{SiO}_{2}$ (a), as-synthesized $\mathrm{Fe}_{2} \mathrm{O}_{3} / \mathrm{SiO}_{2}$ (b), TEM image of as-synthesized $\mathrm{Fe}_{2} \mathrm{O}_{3} / \mathrm{SiO}_{2}$ (c) and EDS spectrum of as-synthesized $\mathrm{Fe}_{2} \mathrm{O}_{3} / \mathrm{SiO}_{2}$ (d)

\subsubsection{XRD analysis}

The XRD patterns of the $\mathrm{SiO}_{2}$ and as-synthesized $\mathrm{Fe}_{2} \mathrm{O}_{3} / \mathrm{SiO}_{2}$ composite are shown in Figure 2. The diffraction peak at $2 \theta=22^{\circ}$ was assigned to amorphous silica and the other peaks at $2 \theta$ from 30 to $50^{\circ}$ could be assigned to $\mathrm{CaSO}_{4}$ content in commercial $\mathrm{SiO}_{2}$ [6]. For a composite, the XRD pattern peaks at $2 \theta=25,32,41$ and $49^{\circ}$ were broad and low intensity indicating the low content, low degree of crystallinity, and well dispersion of small particle of $\mathrm{Fe}_{2} \mathrm{O}_{3}$ in the composite. In addition, the disappearance of diffraction peaks of $\mathrm{CaSO}_{4}$ indicated that $\mathrm{CaSO}_{4}$ converted into amorphous form after heat treatment at $500{ }^{\circ} \mathrm{C}$ for $5 \mathrm{~h}$.

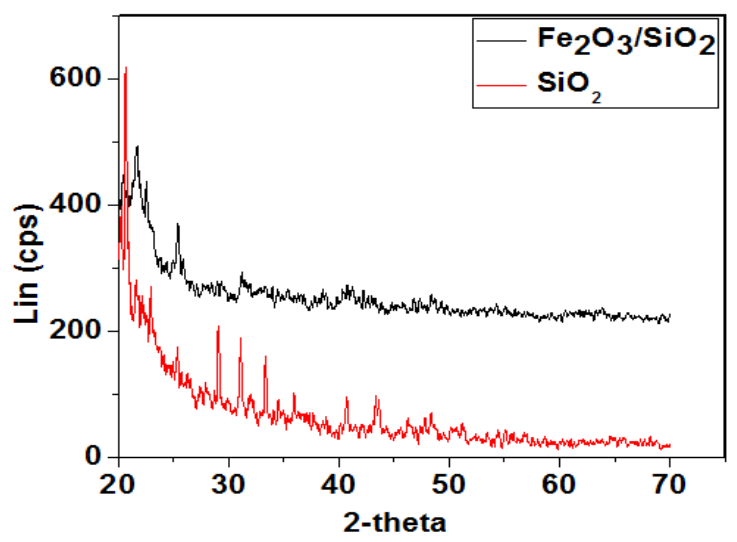

Figure 2: XRD pattern of $\mathrm{SiO}_{2}$ and as-synthesized $\mathrm{Fe}_{2} \mathrm{O}_{3} / \mathrm{SiO}_{2}$ composite

\subsection{3. $\mathrm{N}_{2}$ adsorption-desorption isotherm}

Typical $\mathrm{N}_{2}$ adsorption-desorption isotherms and pore size distributions of $\mathrm{SiO}_{2}$ and as-synthesized $\mathrm{Fe}_{2} \mathrm{O}_{3} / \mathrm{SiO}_{2}$ samples are presented in figure 3. The isotherm curves were classified as type IV with type H1 hysteresis loops according to the UIPAC classification, indicating the mesoporous material consisting of well-defined cylindrical-like pore channels or agglomerates of compacts of approximately uniform spheres. The shape of the hysteresis loop of as-synthesized $\mathrm{Fe}_{2} \mathrm{O}_{3} / \mathrm{SiO}_{2}$ was similar to that of $\mathrm{SiO}_{2}$, but the hysteresis level of assynthesized $\mathrm{Fe}_{2} \mathrm{O}_{3} / \mathrm{SiO}_{2}$ was lower. The adsorptiondesorption braches of the hysteresis loop at relative pressure $\mathrm{p} / \mathrm{p}_{0}$ of $0.78 / 0.96$ and $0.87 / 0.98$ for $\mathrm{Fe}_{2} \mathrm{O}_{3} / \mathrm{SiO}_{2}$ and $\mathrm{SiO}_{2}$, respectively.

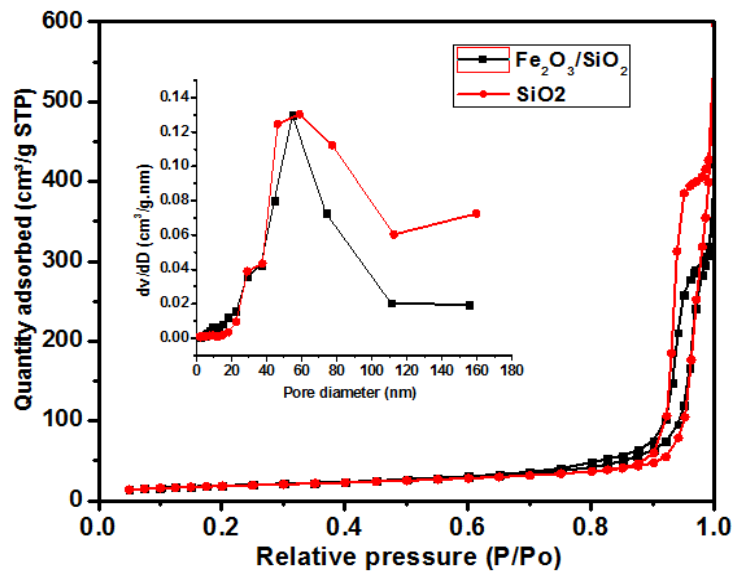

Figure 3: $\mathrm{N}_{2}$ adsorption/desorption isotherm of (inset: pore size distributions) of $\mathrm{SiO}_{2}$ and assynthesized $\mathrm{Fe}_{2} \mathrm{O}_{3} / \mathrm{SiO}_{2}$ composite 
The pore size distribution of $\mathrm{SiO}_{2}$ was broader than that of as-synthesized $\mathrm{Fe}_{2} \mathrm{O}_{3} / \mathrm{SiO}_{2}$, this can be ascribed to the re-structure of $\mathrm{SiO}_{2}$ and well distribute of ion in the composite. The pore size distributions of both samples were comparatively concentrated at around $30-70 \mathrm{~nm}$. The average pore diameters of $\mathrm{SiO}_{2}$ and as-synthesized $\mathrm{Fe}_{2} \mathrm{O}_{3} / \mathrm{SiO}_{2}$ were 40.3 and $28.8 \mathrm{~nm}$, respectively, as shown in table 1. The surface area of as-synthesized $\mathrm{Fe}_{2} \mathrm{O}_{3} / \mathrm{SiO}_{2}$ slightly increased but pore volume was decreased compared to those of $\mathrm{SiO}_{2}$. These results indicated that the good dispersion of $\mathrm{Fe}_{2} \mathrm{O}_{3}$ by using our simple incipient impregnation method could give a small effect to textural properties of samples.

Table 1: Textural properties of $\mathrm{SiO}_{2}$ and as-synthesized $\mathrm{Fe}_{2} \mathrm{O}_{3} / \mathrm{SiO}_{2}$ composite

\begin{tabular}{|c|c|c|c|}
\hline Sample & $\begin{array}{c}\mathrm{S}_{\mathrm{BET}} \\
\left(\mathrm{m}^{2} / \mathrm{g}\right)\end{array}$ & $\begin{array}{c}\text { Vpore } \\
\left(\mathrm{cm}^{3} / \mathrm{g}\right)\end{array}$ & $\begin{array}{c}\text { Dpore }^{\mathrm{a}} \\
(\mathrm{nm})\end{array}$ \\
\hline $\mathrm{SiO}_{2}$ & 64 & 0.61 & 40.27 \\
\hline $\mathrm{Fe}_{2} \mathrm{O}_{3} / \mathrm{SiO}_{2}$ & 66 & 0.49 & 28.80 \\
\hline
\end{tabular}

${ }^{\mathrm{a} A v e r a g e ~ p o r e ~ s i z e . ~}$

\subsection{Degradation of tartrazine}

Figure 4 shows the degradation of tartrazine in different reaction systems. The degradation efficiency was about $2.9 \%$ when only $\mathrm{H}_{2} \mathrm{O}_{2}$ was in dye solution within $80 \mathrm{~min}$, in figure $4 \mathrm{a}$. This indicated that tartrazine was stable and hardly degraded in the presence of $\mathrm{H}_{2} \mathrm{O}_{2}$ even thought $\mathrm{H}_{2} \mathrm{O}_{2}$ was a powerful oxidizing agent. For reaction system with only $\mathrm{SiO}_{2}$ or $\mathrm{Fe}_{2} \mathrm{O}_{3} / \mathrm{SiO}_{2}$, the degradation efficiency was also negligible, 0.7 and $1.6 \%$ for $\mathrm{SiO}_{2}$ and $\mathrm{Fe}_{2} \mathrm{O}_{3} / \mathrm{SiO}_{2}$ as shown in figures $4 \mathrm{~b}$ and $\mathrm{c}$, respectively. The change of dye concentration was due to the adsorption on $\mathrm{SiO}_{2}$ and $\mathrm{Fe}_{2} \mathrm{O}_{3} / \mathrm{SiO}_{2}$. The higher adsorption of tartrazine on $\mathrm{Fe}_{2} \mathrm{O}_{3} / \mathrm{SiO}_{2}$ than that of $\mathrm{SiO}_{2}$ was due to tartrazine being negatively charged in aqueous solution, whereas positively charged iron (III) ions on the $\mathrm{Fe}_{2} \mathrm{O}_{3} / \mathrm{SiO}_{2}$ could increase the electrostatic adsorption of tartrazine.

The reaction rate of tartrazine for commercial $\mathrm{Fe}_{2} \mathrm{O}_{3} / \mathrm{H}_{2} \mathrm{O}_{2} /$ dye and as-synthesized $\mathrm{Fe}_{2} \mathrm{O}_{3} / \mathrm{H}_{2} \mathrm{O}_{2} /$ dye systems (Figure $4 \mathrm{~d}$ and e) were fast within an initial $10 \mathrm{~min}$, it becomes more stable. The degradation efficiencies were 9.6 and $1.6 \%$, respectively for commercial $\mathrm{Fe}_{2} \mathrm{O}_{3} / \mathrm{H}_{2} \mathrm{O}_{2} /$ dye and as-synthesized $\mathrm{Fe}_{2} \mathrm{O}_{3} / \mathrm{H}_{2} \mathrm{O}_{2} /$ dye, respectively, in $80 \mathrm{~min}$. The reaction rate of tartrazine for the physical mixture $\mathrm{Fe}_{2} \mathrm{O}_{3} / \mathrm{SiO}_{2} / \mathrm{H}_{2} \mathrm{O}_{2} /$ dye system (figure $4 \mathrm{f}$ ) was slow, its removal efficiency was $13.5 \%$ in $80 \mathrm{~min}$. The catalytic activity of $\mathrm{Fe}_{2} \mathrm{O}_{3}$ with $\mathrm{SiO}_{2}$ was higher than that of single metal systems $\mathrm{Fe}_{2} \mathrm{O}_{3}$. It reveals that $\mathrm{SiO}_{2}$ can be used as a supporter to improve the removal efficiency of tartrazine in presence of $\mathrm{H}_{2} \mathrm{O}_{2}$.
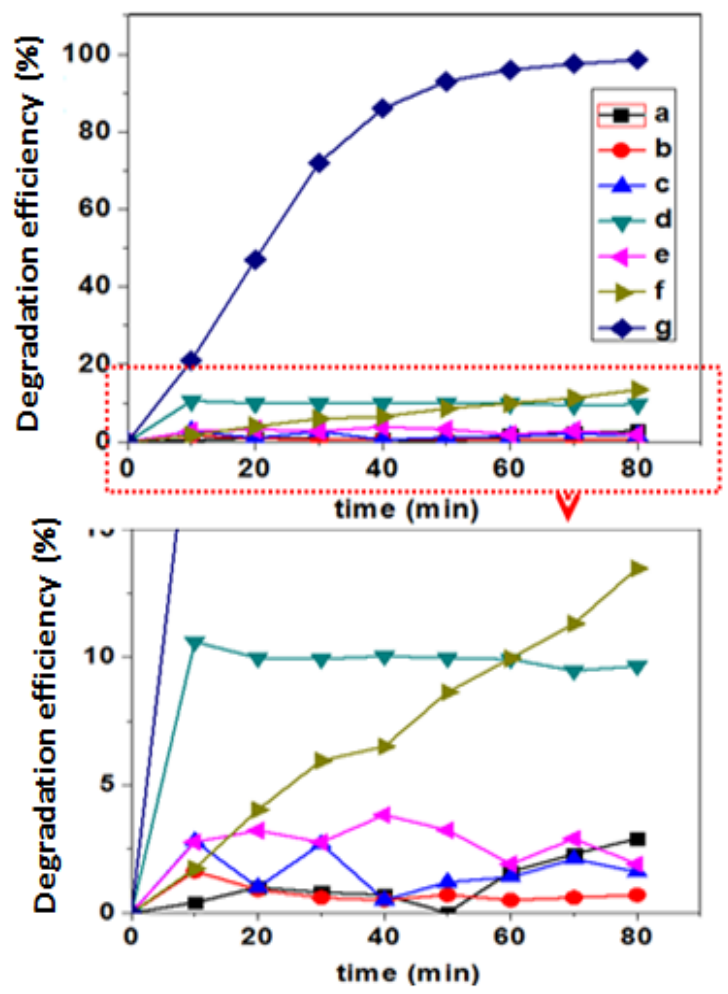

Figure 4: The degradation of tartrazine in different reaction systems. Reaction conditions: (a) $\mathrm{H}_{2} \mathrm{O}_{2}$ /dye, (b) $\mathrm{SiO}_{2} /$ dye, (c) $\mathrm{Fe}_{2} \mathrm{O}_{3} / \mathrm{SiO}_{2} /$ dye, (d) Commercial $\mathrm{Fe}_{2} \mathrm{O}_{3} / \mathrm{H}_{2} \mathrm{O}_{2} /$ dye, (e) as-synthesized $\mathrm{Fe}_{2} \mathrm{O}_{3} / \mathrm{H}_{2} \mathrm{O}_{2} /$ dye, (f) physical mixture $\mathrm{Fe}_{2} \mathrm{O}_{3} / \mathrm{SiO}_{2} / \mathrm{H}_{2} \mathrm{O}_{2} /$ dye, (g) assynthesized $\mathrm{Fe}_{2} \mathrm{O}_{3} / \mathrm{SiO}_{2} / \mathrm{H}_{2} \mathrm{O}_{2} /$ dye. (50 mg of catalyst, $50 \mathrm{mg} / \mathrm{L}$ of tartrazine, $12 \mathrm{mM}$ of $\mathrm{H}_{2} \mathrm{O}_{2}$, $\mathrm{pH}=3.0$, temperature of $30^{\circ} \mathrm{C}$ )

The degradation of tatrazine in the commercial $\mathrm{Fe}_{2} \mathrm{O}_{3} / \mathrm{H}_{2} \mathrm{O}_{2} /$ dye, as-synthesized $\mathrm{Fe}_{2} \mathrm{O}_{3} / \mathrm{H}_{2} \mathrm{O}_{2} /$ dye, and physical mixture $\mathrm{Fe}_{2} \mathrm{O}_{3} / \mathrm{SiO}_{2} / \mathrm{H}_{2} \mathrm{O}_{2} /$ dye systems could be attributed to Fenton-like system oxidation. In addition to the Fenton-like reaction that lead to the formation of $\mathrm{OH}^{\bullet}$ and the decomposition of $\mathrm{H}_{2} \mathrm{O}_{2}$ by $\mathrm{Fe}_{2} \mathrm{O}_{3}$ via heterogeneous catalysis has also been reported to yield hydroxyl and superoxide radicals [7]. The reaction ability of tartrazine for assynthesized $\mathrm{Fe}_{2} \mathrm{O}_{3} / \mathrm{SiO}_{2} / \mathrm{H}_{2} \mathrm{O}_{2} /$ dye (Figure $4 \mathrm{~g}$ ) was much higher than other systems and the removal efficiency reached $98.5 \%$ in $80 \mathrm{~min}$. As presented in section 3.1.3, the surface area of as-synthesized $\mathrm{Fe}_{2} \mathrm{O}_{3} / \mathrm{SiO}_{2}$ was not much different to $\mathrm{SiO}_{2}$ but pore volume was decreased after impregnation. It was expected that the same results with the physical mixture $\mathrm{Fe}_{2} \mathrm{O}_{3} / \mathrm{SiO}_{2}$ for the low content of ion. However, the existence of Si-O-Fe bond in as- 
synthesized $\mathrm{Fe}_{2} \mathrm{O}_{3} / \mathrm{SiO}_{2}$ [8] indicating the interaction between silica and iron ions. Thus, iron disperses within the pores of silica and surface of the silica support. This may be unclear in the physical mixture $\mathrm{Fe}_{2} \mathrm{O}_{3} / \mathrm{SiO}_{2}$. Therefore, with regard to surface area and pore volume of physical mixture $\mathrm{Fe}_{2} \mathrm{O}_{3} / \mathrm{SiO}_{2}$ and as-synthesized $\mathrm{Fe}_{2} \mathrm{O}_{3} / \mathrm{SiO}_{2}$, the dispersion of $\mathrm{Fe}_{2} \mathrm{O}_{3}$ on $\mathrm{SiO}_{2}$ structure showed more important factor than textural properties of composite materials. This result indicated that $\mathrm{Fe}_{2} \mathrm{O}_{3}$ on the surface of the $\mathrm{SiO}_{2}$ prepared by incipient impregnation method has a higher dispersion than that of physical mixture method.

\subsection{Effect of initial solution $\mathbf{p H}$}

The effect of initial solution $\mathrm{pH}$ on degradation of tartrazine on as-synthesized $\mathrm{Fe}_{2} \mathrm{O}_{3} / \mathrm{SiO}_{2} / \mathrm{H}_{2} \mathrm{O}_{2} /$ dye system was investigated. The $\mathrm{pH}$ values were varied from 2.0 to 6.0 while other conditions were fixed (inital tartrazine concentration of $50 \mathrm{mg} / \mathrm{L}, 50 \mathrm{mg}$ of the catalyst, $\mathrm{H}_{2} \mathrm{O}_{2}$ concentration of $12 \mathrm{mM}$, and temperature of $30{ }^{\circ} \mathrm{C}$ ) and the results are shown in figure 5 .

Overall results indicated that the degradation of tartrazine was significantly influenced by the solution $\mathrm{pH}$. The reaction rate at $\mathrm{pH} 2.5$ was slightly lower than that at $\mathrm{pH} 3.0$ but the degradation efficiency at both $\mathrm{pH}$ values 2.5 and 3.0 reached $98.5 \%$ in $80 \mathrm{~min}$. The solution $\mathrm{pH} 3.0$ was more suitable than 2.5 because it allows using less acid to acidify the medium and lower ion leaching is produced. This is in agreement with the classical Fenton. At $\mathrm{pH}$ lower than 2.5, the reaction rate was decreased and the degradation efficiency decreased to $39.7 \%$ in $80 \mathrm{~min}$ at $\mathrm{pH} 2.0$. The reaction rate was slowed down might be attributed to the stabilization of $\mathrm{H}_{2} \mathrm{O}_{2}$ through the formation of oxonium ion $\left(\mathrm{H}_{3} \mathrm{O}_{2}{ }^{+}\right)$leading to substantially reduce the reactivity with the ferrous ion. In addition, the Fenton reaction was retarded due to the scaveging effect of hydroxyl radicals $\left(\mathrm{OH}^{\circ}\right)$ by overbundance of $\mathrm{H}^{+}$ion at low $\mathrm{pH}$ [9] as the equation follows.

$$
\mathrm{OH}^{\bullet}+\mathrm{H}^{+}+\mathrm{e}=\mathrm{H}_{2} \mathrm{O}
$$

Furthermore, formed complex species $[\mathrm{Fe}$ $\left.\left(\mathrm{H}_{2} \mathrm{O}\right)_{6}\right]^{2+}$ and $\left[\mathrm{Fe}\left(\mathrm{H}_{2} \mathrm{O}\right)_{6}\right]^{3+}$ also react more slowly with $\mathrm{H}_{2} \mathrm{O}_{2}$ [10].

At greater $\mathrm{pH}$ value than 3.0, the reaction rate was rapidly decreased with an increase of $\mathrm{pH}$. The degradation efficiencies at $\mathrm{pH}=3.5,4.0$ and 6.0 were $64.3,7.9$ and $1.1 \%$, respectively. In the previous report [8], at high $\mathrm{pH}$ value, $\mathrm{Fe}_{2} \mathrm{O}_{3} / \mathrm{SiO}_{2}$ solid catalyst surface becomes negatively charged making interaction with tartrazine dye less frequent and a part of $\mathrm{H}_{2} \mathrm{O}_{2}$ undergoes self-decomposition into molecular oxygen without appreciable amounts of radicals in the less acidic medium leading to lose the oxidizing ability. In addition, the deactivation of catalyst with the formation of ferric hydroxide complexes leads to a reduction of $\mathrm{OH}^{\bullet}$ radical. As a result, reaction rate and degradation efficiency of tartrazine in as-synthesized $\mathrm{Fe}_{2} \mathrm{O}_{3} / \mathrm{SiO}_{2} / \mathrm{H}_{2} \mathrm{O}_{2} /$ dye at greater $\mathrm{pH}$ than 3.0 were dropped.
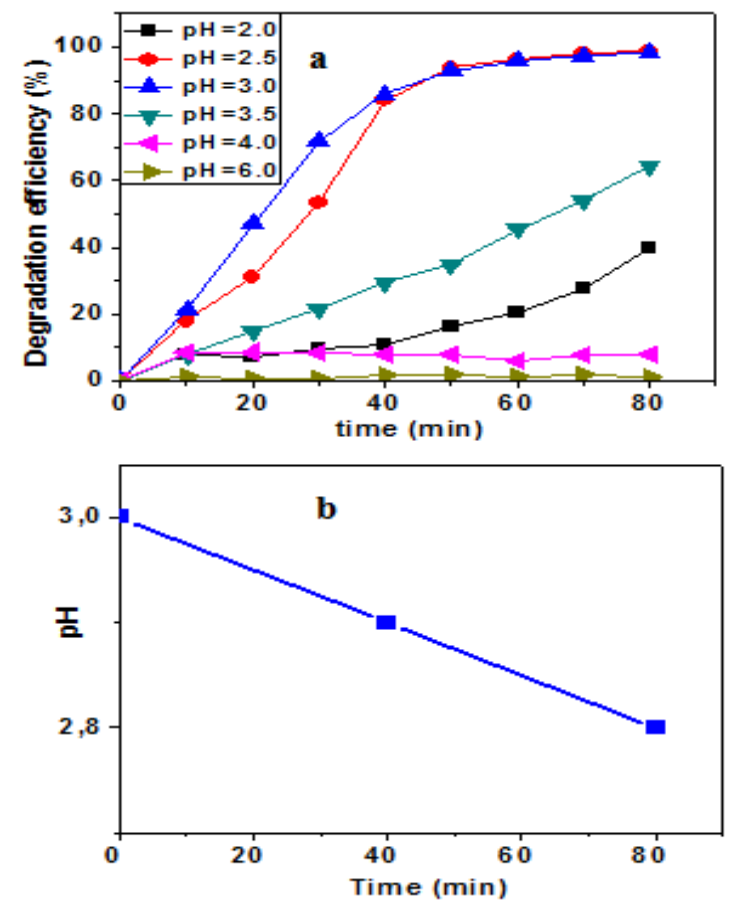

Figure 5: (a) Effect of initial solution $\mathrm{pH}$ and (b) $\mathrm{pH}$ drop versus time with initial solution $\mathrm{pH}$ 3.0. At condition: $50 \mathrm{mg} / \mathrm{L}$ of tartrazine, $\mathrm{H}_{2} \mathrm{O}_{2}$ concentration of $12 \mathrm{mM}, 50 \mathrm{mg}$ of catalyst and temperature of $30{ }^{\circ} \mathrm{C}$

We observed that the solution $\mathrm{pH}$ has a critical impact on the degradation of tartrazine because of its role in controlling the catalytic reaction, resulting in iron ions and the stability of $\mathrm{H}_{2} \mathrm{O}_{2}$. The optimum $\mathrm{pH}$ was found to be 3.0 in which the reaction a good catalytic and could respond to $\mathrm{H}_{2} \mathrm{O}_{2}$ to produce ${ }^{\mathrm{O}} \mathrm{H} \cdot$ radicals to degrade the tartrazine dye molecules. At initial solution $\mathrm{pH} 3.0$, the drop of $\mathrm{pH}$ during reaction was slight. The $\mathrm{pH}$ value decreased to 2.9 in first $40 \mathrm{~min}$ and final to 2.8 after $80 \mathrm{~min}$ of reaction when initial solution $\mathrm{pH}$ was 3.0, as shown in Figure $5 \mathrm{~b}$. The decrease of $\mathrm{pH}$ value could be attributed to the formation of $\mathrm{HNO}_{3}, \mathrm{H}_{2} \mathrm{SO}_{4}$, and other organic acids such as oxalic acid, acetic acid, and succinic acid [11].

\subsection{Effect of initial $\mathrm{H}_{2} \mathrm{O}_{2}$ concentration}

The concentration of $\mathrm{H}_{2} \mathrm{O}_{2}$ is critical for the degradation of the tartrazine dye during Fenton 
oxidation. The impact of $\mathrm{H}_{2} \mathrm{O}_{2}$ concentration on the degradation of tartrazine in as-synthesized $\mathrm{Fe}_{2} \mathrm{O}_{3} / \mathrm{SiO}_{2} / \mathrm{H}_{2} \mathrm{O}_{2} /$ dye is shown in figure 6 . The concentration of $\mathrm{H}_{2} \mathrm{O}_{2}$ was varied from 6 to $60 \mathrm{mM}$, while other conditions remained at the constant (initial tartrazine concentration of $50 \mathrm{mg} / \mathrm{L}$, catalyst dosage of $50 \mathrm{mg}, \mathrm{pH} \mathrm{3.0}$, and temperature of $30^{\circ} \mathrm{C}$ ). The reaction rate at a $\mathrm{H}_{2} \mathrm{O}_{2}$ concentration of $12 \mathrm{mM}$ was larger than that at $6 \mathrm{mM}$ but the degradation efficiencies at these $\mathrm{pH}$ values were not much different to each other, 95.2 and $98.5 \%$ at 6 and 12 $\mathrm{mM}$, respectively. However, the reaction rate and degradation efficiency were gradually reduced as the $\mathrm{H}_{2} \mathrm{O}_{2}$ concentration increased to more than $12 \mathrm{mM}$, it was $97.0,95.0$, and $88.0 \%$ at $\mathrm{H}_{2} \mathrm{O}_{2}$ concentration of $18,30,60 \mathrm{mM}$, respectively. The increase of the oxidant concentration from 6.0 to $12 \mathrm{mM}$ led to increasing degradation efficiency of dye because more $\mathrm{OH}^{\bullet}$ radicals were formed. However, the high $\mathrm{H}_{2} \mathrm{O}_{2}$ concentration (>12 mM) results in a decrease in degradation process because surplus $\mathrm{H}_{2} \mathrm{O}_{2}$ molecules act as scavenger of hydroxyl radical to generate perhydroxy radical $\left(\mathrm{HO}_{2}^{\circ}\right)$ which has lower oxidation potential than the former. The reaction equation can be expressed as follow [7]:

$$
\mathrm{H}_{2} \mathrm{O}_{2}+\mathrm{OH}^{\bullet} \rightarrow \mathrm{HO}_{2}^{\bullet}+\mathrm{H}_{2} \mathrm{O}
$$

Therefore, the effect of $\mathrm{H}_{2} \mathrm{O}_{2}$ adding for the tartrazine degradation is two sided and the appropriate amount of $\mathrm{H}_{2} \mathrm{O}_{2}$ plays an important role in the degradation process. The $\mathrm{H}_{2} \mathrm{O}_{2}$ concentration of $12 \mathrm{mM}$ was the optimal value for removal of tatrazine by $\mathrm{Fe}_{2} \mathrm{O}_{3} / \mathrm{SiO}_{2}$ composite and it was used to further study.

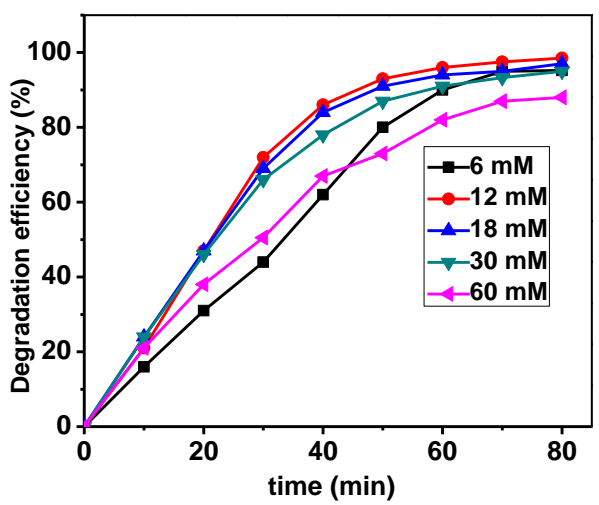

Figure 6: Effect of initial $\mathrm{H}_{2} \mathrm{O}_{2}$ concentration on degradation of tartrazine with reaction conditions: initial tartrazine concentration of $50 \mathrm{mg} / \mathrm{L}$, dosage of catalyst of $50 \mathrm{mg}, \mathrm{pH} 3.0$, and temperature of $30{ }^{\circ} \mathrm{C}$

\subsection{Effect of additive ( $\mathrm{NaCl}$ and EDTA)}

Industrial wastewater might contain the inorganic salts (sodium chloride, potassium chloride, sodium sulphate, potassium sulphate, etc.) which were electrolytes and organic agent (EDTA, tartaric acid, formic acid, glycine, nitrilotriacetic acid, etc.) which were iron-ligands. Therefore, it was thought worthwhile to investigate the effects of dissolute salt and chelating agents $(\mathrm{NaCl}$ and EDTA were selected, respectively) on the degradation of dye by $\mathrm{Fe}_{2} \mathrm{O}_{3} / \mathrm{SiO}_{2}$ catalyst. The effects of $\mathrm{NaCl}$ and EDTA additives were studied only at optimum concentration of dye, $\mathrm{H}_{2} \mathrm{O}_{2}$, and $\mathrm{pH}$, the results are shown in figure 7 . The reaction rate was slightly decreased with an addition of $\mathrm{NaCl}(20 \mathrm{mg})$, the degradation efficiency decreased to $95 \%$ indicating that $\mathrm{NaCl}$ played a passive role in the degradation of tartrazine in $\mathrm{Fe}_{2} \mathrm{O}_{3} / \mathrm{SiO}_{2} / \mathrm{H}_{2} \mathrm{O}_{2}$ system. The negative effect of $\mathrm{NaCl}$ in common advance oxidation process technologies has been studied in previous reports [12]. In the presence of sodium chloride, $\mathrm{Cl}^{-}$ ions could react with the active radical during the reaction process, causing a decrease in the degradation rate, (equations (4) - (6)) [13].

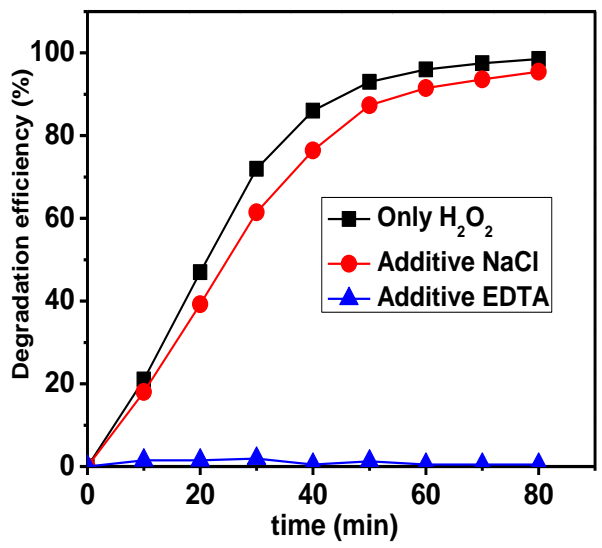

Figure 7: Effect of $\mathrm{NaCl}$ and EDTA on degradation of tartrazine with reaction conditions: $50 \mathrm{mg}$ of catalyst, $50 \mathrm{mg} / \mathrm{L}$ of dye, $12 \mathrm{mM}$ of $\mathrm{H}_{2} \mathrm{O}_{2}, \mathrm{pH} 3.0,20$ $\mathrm{mg}$ of $\mathrm{NaCl} / 20 \mathrm{mg}$ of EDTA, temperature of $30^{\circ} \mathrm{C}$

$$
\begin{aligned}
\mathrm{Cl}^{-}+\mathrm{OH}^{\bullet} & =\mathrm{ClOH}^{\bullet-} \\
\mathrm{ClOH}^{\bullet-}+\mathrm{H}^{+} & =\mathrm{Cl}^{\bullet}+\mathrm{H}_{2} \mathrm{O} \\
\mathrm{ClOH}^{\bullet-}+\mathrm{Fe}^{2+} & =\mathrm{Cl}^{-}+\mathrm{OH}^{-}+\mathrm{Fe}^{3+}
\end{aligned}
$$

In the presence of the chelating agent, the reaction rate tartrazine was decreased significantly and the degradation efficiency was neglected with an addition EDTA of $20 \mathrm{mg}$. The mechanism of the heterogeneous Fenton reactions in the presence of chelating agents EDTA remains unclear, due to the possible concurrence of homogeneous and heterogeneous reactions. Chelating agents can induce an enhanced homogeneous Fenton mechanism by increasing the dissolution of solid catalysts. In contrast, the surface complexed ligands can compete for the surface active sites with organic 
compounds and $\mathrm{H}_{2} \mathrm{O}_{2}$ leading to a decreased $\mathrm{H}_{2} \mathrm{O}_{2}$ activation $[14,15]$ and the generation of high-valent iron species is also speculated according to some inhibitive effects of different scavengers [16]. In this study, the insignificant decrease in degradation of dye at $\mathrm{pH} 3.0$ may be due to the decrease of $\mathrm{H}_{2} \mathrm{O}_{2}$ activation. This will hinder the heterogeneous and homogeneous reaction. However, it cannot be certainly declared that the negative effect of the presence of EDTA in the Fenton-like reaction systems for degradation of dye. The degradation of bisphenol A (BPA) was decreased from 87.0 to 20.4 in the EDTA- $\mathrm{H}_{2} \mathrm{O}_{2}-\mathrm{BiOFeO}_{3}$ systems at $\mathrm{pH}=3.0$. The degradation efficiency increased when $\mathrm{pH}$ solution increased [17]. The similar phenomena occurred in other reports [16]. Thus, the effect of $\mathrm{pH}$ value is a crucial factor for degradation of dye and the result in removal of tartrazine in the EDTA$\mathrm{H}_{2} \mathrm{O}_{2}-\mathrm{Fe}_{2} \mathrm{O}_{3} / \mathrm{SiO}_{2}$ system is going to be presented in the next report.

\subsection{Reaction mechanism discussion}

Figure 8 shows the change with time in UV-Vis spectra of tartrazine degradation during $80 \mathrm{~min}$ of reaction period. As can be seen from dye spectrum, before oxidation $(t=0)$, the absorption spectrum of tartrazine dye was characterized by one band in the ultraviolet region located at $257 \mathrm{~nm}$ and by one band in visible region which its maximum absorption at $428 \mathrm{~nm}$. The peak at $257 \mathrm{~nm}$ is due to benzene-like structure in the molecules while the band in the visible region was associated with the chromophorecontaining azo linkage. The disappearance of the absorbance pic at $428 \mathrm{~nm}$ with the time was due to the fragmentation of the azo links by oxidation. In addition to this rapid degradation effect, the decay of

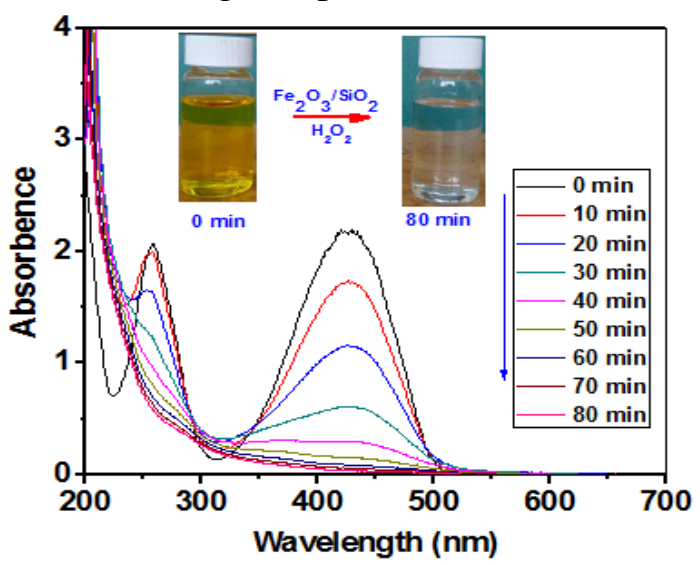

Figure 8: UV-Vis spectra during degradation process with as-synthesized $\mathrm{Fe}_{2} \mathrm{O}_{3} / \mathrm{SiO}_{2} / \mathrm{H}_{2} \mathrm{O}_{2} /$ dye systems. $\left(50 \mathrm{mg} / \mathrm{L}\right.$ of tartrazine, $\mathrm{H}_{2} \mathrm{O}_{2}$ concentration of $12 \mathrm{mM}$, dosage of catalyst $50 \mathrm{mg}, \mathrm{pH} 3.0$, temperature $30{ }^{\circ} \mathrm{C}$ ) the absorbance at $257 \mathrm{~nm}$ was considered as an evidence of aromatic fragment degradation in the dye molecule and its intermediates [18-20].

\section{CONCLUSION}

In this study, the $\mathrm{Fe}_{2} \mathrm{O}_{3} / \mathrm{SiO}_{2}$ composite has been successfully prepared via a simple impregnation method. The $\mathrm{Fe}_{2} \mathrm{O}_{3}$ with small particle size was highly dispersed on silica and exhibited excellent efficiency for the Fenton degradation of tartrazine, $98.5 \%$ in 80 min. It was much higher than that of physic mixture $\mathrm{Fe}_{2} \mathrm{O}_{3} / \mathrm{SiO}_{2}$, and other materials. The effects of $\mathrm{H}_{2} \mathrm{O}_{2}$ concentration, $\mathrm{pH}$ on reaction rate were investigated. The optimal parameters obtained for this investigation were found to be $2.0 \mathrm{mM}$ of $\mathrm{H}_{2} \mathrm{O}_{2}, \mathrm{pH} 3.0$, at $30{ }^{\circ} \mathrm{C}$ under maintaining condition $50 \mathrm{mg}$ of catalyst, $50 \mathrm{mg} / \mathrm{L}$ of dye. The addition of $\mathrm{NaCl}$ and EDTA played a passive role in the degradation of dye. In which, EDTA showed much strong decrease in reaction rate and degradation efficiency of dye by as-synthesized $\mathrm{Fe}_{2} \mathrm{O}_{3} / \mathrm{SiO}_{2}$ composite compared to that of $\mathrm{NaCl}$.

\section{REFERENCES}

1. Ahmed M. A., E. E. El-Katori, and Z. H. Gharni. Photocatalytic degradation of methylene blue dye using $\mathrm{Fe}_{2} \mathrm{O}_{3} / \mathrm{TiO}_{2}$ nanoparticles prepared by sol-gel method, Journal of Alloys and Compounds, 553, 1929 (2013).

2. Yu L., J. Chen, Z. Liang, W. Xu, L. Chen, and D. Ye. Degradation of phenol using $\mathrm{Fe}_{3} \mathrm{O}_{4}-\mathrm{GO}$ nanocomposite as a heterogeneous photo-Fenton catalyst, Separation and Purification Technology, 171, 80-87 (2016).

3. Dias F. F., A. A. S. Oliveira, A. P. Arcanjo, F. C. C. Moura, and J. G. A. Pacheco. Residue-based iron catalyst for the degradation of textile dye via heterogeneous photo-Fenton, Applied Catalysis B: Environmental, 186, 136-142 (2016).

4. Wang Y., H. Zhao, and G. Zhao. Iron-copper bimetallic nanoparticles embedded within ordered mesoporous carbon as effective and stable heterogeneous Fenton catalyst for the degradation of organic contaminants, Applied Catalysis B: Environmental, 164, 396-406 (2015).

5. Gautam R. K., P. K. Gautam, S. Banerjee, V. Rawat, S. Soni, S. K. Sharma, and M. C. Chattopadhyaya. Removal of tartrazine by activated carbon biosorbents of Lantana camara: Kinetics, equilibrium modeling and spectroscopic analysis, Journal of Environmental Chemical Engineering, 3, 79-88 (2015).

6. Kadari A., K. Mahi, R. Mostefa, M. Badaoui, A. Mameche, and D. Kadri. Optical and structural 
properties of $\mathrm{Mn}$ doped $\mathrm{CaSO}_{4}$ powders synthesized by sol-gel process, Journal of Alloys and Compounds, 688, Part A: 32-36 (2016).

7. Neamtu, M., A. Yediler, I. Siminiceanu, and A. Kettrup. Oxidation of commercial reactive azo dye aqueous solutions by the photo-Fenton and Fentonlike processes, Journal of Photochemistry and Photobiology A: Chemistry, 161, 87-93 (2003).

8. Soon A. N. and B. H. Hameed. Degradation of Acid Blue 29 in visible light radiation using iron modified mesoporous silica as heterogeneous Photo-Fenton catalyst, Applied Catalysis A: General, 450, 96-105 (2013).

9. Ramirez J. H., C. A. Costa, L. M. Madeira, G. Mata, M. A. Vicente, M. L. Rojas-Cervantes, A. J. LópezPeinado, and R. M. Martín-Aranda. Fenton-like oxidation of Orange II solutions using heterogeneous catalysts based on saponite clay, Applied Catalysis B: Environmental, 71, 44-56 (2007).

10. Hassan H. and B. H. Hameed. Fe-clay as effective heterogeneous Fenton catalyst for the decolorization of Reactive Blue 4, Chemical Engineering Journal, 171, 912-918 (2011).

11. Panda N., H. Sahoo, and S. Mohapatra. Decolourization of Methyl Orange using Fenton-like mesoporous $\mathrm{Fe}_{2} \mathrm{O}_{3}-\mathrm{SiO}_{2}$ composite, Journal of Hazardous Materials, 185, 359-365 (2011).

12. J. Kiwi, A. L., V. Nadtochenko. Mechanism and Kinetics of the OH-Radical Intervention during Fenton Oxidation in the Presence of a Significant Amount of Radical Scavenger $\left(\mathrm{Cl}^{-}\right)$, Environ. Sci. Technol, 34, 2162-2168 (2000).

13. Yao Y., L. Wang, L. Sun, S. Zhu, Z. Huang, Y. Mao, $\mathrm{W}$. Lu, and W. Chen. Efficient removal of dyes using heterogeneous Fenton catalysts based on activated carbon fibers with enhanced activity, Chemical Engineering Science, 101, 424-431 (2013).

14. Matta R., K. Hanna, T. Kone, and S. Chiron. Oxidation of 2,4,6-trinitrotoluene in the presence of different iron-bearing minerals at neutral $\mathrm{pH}$, Chemical Engineering Journal, 144, 453-458 (2008).

15. Xue X., K. Hanna, C. Despas, F. Wu, and N. Deng. Effect of chelating agent on the oxidation rate of $P C P$ in the magnetite $/ \mathrm{H}_{2} \mathrm{O}_{2}$ system at neutral $\mathrm{pH}$, Journal of Molecular Catalysis A: Chemical, 311, 29-35 (2009).

16. He, J., X. Yang, B. Men, L. Yu, and D. Wang. EDTA enhanced heterogeneous Fenton oxidation of dimethyl phthalate catalyzed by $\mathrm{Fe}_{3} \mathrm{O}_{4}$ : Kinetics and interface mechanism. Journal of Molecular Catalysis A: Chemical, 408, 179-188 (2015).

17. Nan Wang, L. Z. Ming Lei, Yuanbin She, Meijuan Cao, Heqing Tang. Ligand-Induced Drastic Enhancement of Catalytic Activity of Nano-BiFeO for Oxidative Degradation of Bisphenol A, ACS Catal., 1, 1193-1202 (2011).

18. Tanaka, K., K. Padermpole, and T. Hisanaga. Photocatalytic degradation of commercial azo dyes, Water Research, 34, 327-333 (2000).

19. Feng X, Z. S., Hou H. Photocatalytic degradation of organic azo dye in aqueous solution using Xeexcimer lamp, Environmental Technology, 27, 119126 (2006).

20. Zhong X., S. Royer, H. Zhang, Q. Huang, L. Xiang, $\mathrm{S}$. Valange, and J. Barrault. Mesoporous silica irondoped as stable and efficient heterogeneous catalyst for the degradation of C.I. Acid Orange 7 using sono-photo-Fenton process, Separation and Purification Technology, 80, 163-171 (2011).

\section{Corresponding author: Vu Anh Tuan}

Hanoi University of Science and Technology, No. 1, Dai Co Viet Road, Hai Ba Trung Dist., Hanoi E-mail: tuan.vuanh@hust.edu.vn; Telephone: 0912911902/01699970227. 